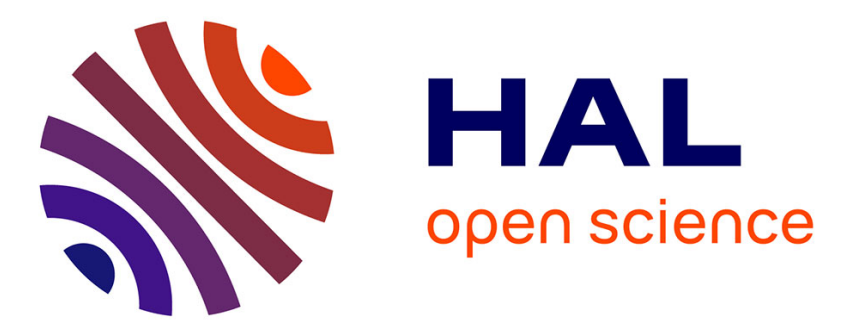

\title{
Soil invertebrate activity in biological crusts on tropical inselbergs
}

Anne Vaçulik, Charlotte Kounda-Kiki, Corinne Sarthou, Jean-François Ponge

\section{To cite this version:}

Anne Vaçulik, Charlotte Kounda-Kiki, Corinne Sarthou, Jean-François Ponge. Soil invertebrate activity in biological crusts on tropical inselbergs. European Journal of Soil Science, 2004, 55 (3), pp.539-549. 10.1111/j.1365-2389.2004.00615.x . hal-00497120

\section{HAL Id: hal-00497120 \\ https://hal.science/hal-00497120}

Submitted on 2 Jul 2010

HAL is a multi-disciplinary open access archive for the deposit and dissemination of scientific research documents, whether they are published or not. The documents may come from teaching and research institutions in France or abroad, or from public or private research centers.
L'archive ouverte pluridisciplinaire HAL, est destinée au dépôt et à la diffusion de documents scientifiques de niveau recherche, publiés ou non, émanant des établissements d'enseignement et de recherche français ou étrangers, des laboratoires publics ou privés. 


\title{
Soil invertebrate activity in biological crusts on tropical inselbergs
}

\author{
A.VAÇULIK, C. KOUNDA-KIKI, C. SARTHOU \& J.F. PONGE \\ Muséum National d'Histoire Naturelle, CNRS UMR 5176, 4 Avenue du Petit-Château, \\ 91800 Brunoy, France
}

\section{Summary}

Granite inselbergs protrude from forest and savanna in the tropics. They are exposed to harsh climates (alternation of heavy rain and severe drought) and provide little nutrient for plants. Soil animals and humus components were investigated in cyanobacterial crusts close to patches of epilithic vegetation on the surface of the Nouragues inselberg (French Guiana). Three biological crust samples, corresponding to bromeliacean carpets of increasing size (supposed of increasing age), were sampled for faunal and micromorphological studies. Arthropods (mainly mites and insects) were abundant and highly diversified, the more so after enchytraeid worms ate and tranformed the cyanobacterial mass. Below the superficial cyanobacterial crust, humus was made of a loose assemblage of enchytraeid faeces where these animals were present, or of a compact assemblage of cyanobacteria and amorphous organic matter where mites were the dominant animal group. Roots abounded in the humified part of the crust. We conclude that soil invertebrates, in particular enchytraeid worms, are important for the accumulation of organic matter on granite outcrops, and so therefore for the encroachment of plant succession.

Correspondence: J.F. Ponge. E-mail: jean-francois.ponge@wanadoo.fr 
Running title: Soil invertebrate activity in biological crusts

\section{Introduction}

Inselbergs protrude from rain forests and savannas in the tropics. They support an epilithic vegetation which differs abruptly from that on the surrounding land. Plant successional trajectories have been described in several instances, pointing on difficulties for the establishment of woody vegetation. Vegetation needs to cope with strong erosion, caused by heavy storms and lack of protection, alternation of severe drought and heavy rain and abrupt changes in temperature. Filamentous cyanobacteria with heterocysts are particularly well-adapted to these harsh environments, since they live autotrophically for carbon and nitrogen in the absence of soil, can recover after desiccation and take opportunity of short wet periods for growth and reproduction (Belnap, 2001). Cyanobacteria are most responsible for mineral weathering through the excretion of organic acids and repiration. Despite the common occurrence of cyanobacterial biofilms on rock surfaces, differences in the development of higher vegetation have been recorded according to countries and even in the same country, as a result of weak exchange of diaspores between isolated outcrops (Sarthou et al., 2003). In French Guiana, the Bromeliaceae Pitcairnia geyskesii L.B. Smith is common on well-drained slopes, while forbs and herbs abound around temporary rain-fed ponds. This species is the dominant component of low vegetation, locally called 'savane-roche' (Sarthou \& Grimaldi, 1992). At this stage biological crusts, a few centimetres thick, occur at the contact between bromeliacean carpets and cyanobacterial biofilms (Figure 1). These crusts constitute the first step in the development of humus, and they are niches for the establishment by seed of several plant species. In later stages of soil 
development, organic matter may accumulate to a depth of several decimetres, together with the appearance of a higher, woody vegetation which sheds litter and protects the ground from rapid desiccation.

We may wonder to what extent animals living in cyanobacterial crusts of tropical inselbergs differ from those in other organic soils and biological crusts and whether they affect the genesis of the soil. Do they contribute to the accumulation of a stable structure in these frequently disturbed environments, or are they only subordinate members of a microbial-dominant biocenosis? The answer may also help to throw light on the role of soil animals in primary successions, since previous studies (Ponge et al., 1998) have shown that soil animals play a decisive role in the regeneration of mountain coniferous forests.

\section{Study site}

We studied the crusts on the Nouragues inselberg, which is $100 \mathrm{~km}$ SSE of Cayenne (French Guiana) at $4^{\circ} 5^{\prime} \mathrm{N}$ and $52^{\circ} 42^{\prime} \mathrm{W}$, with its peak at $430 \mathrm{~m}$ above sea level and protruding from the rain forest. The rock is a tabular outcrop of pinkish Caribbean granite, containing $27 \%$ potassium-feldspar, $37 \%$ plagioclase, $33 \%$ coarse-grained quartz and 2\% accessory minerals (Grimaldi \& Riéra, 2001). The inselberg is domeshaped and elongated from East to West. It lacks any forest cover on the eastern flank, where rock is denuded or covered by savane-roche vegetation. The rock is covered by cyanobacterial biofilms made of several species of filamentous cyanobacteria, among which the genera Stigonema, Scytonema and Schizothrix are dominant on free-drained slopes. The dominant plant species is the Bromeliaceae Pitcairnia geyskesii, which 
forms dense, continuous carpets that cover flat and moderately sloping areas. On the periphery of these impenetrable, spiny carpets, are cyanobacterial crusts (Figure 1), especially in the upslope part. Pitcairnia geyskesii and Clusia minor L. establish themselves from seed, and mosses and lichens develop in these spongy, undulating crusts, which can collect water and nutrients (Sarthou \& Grimaldi, 1992). The crusts are thus the main regeneration niche of the savane roche.

\section{Materials and methods}

Selection of sampling plots

We sampled the soil fauna and humus profiles at the upslope border of three bromeliacean carpets of varying size, considered as representative of the variation we observed on the inselberg. Pit1 was a micro-carpet $(60 \mathrm{~cm}$ diameter $)$ made of only a few rosettes of $P$. geyskesii, Pit2 was a small carpet (3 to $5 \mathrm{~m}$ diameter), and Pit3 was a wide carpet (10-15 m diameter). Supposing that carpets of $P$. geyskesii increase in size in the course of time through the sympodial development of this plant, we judged that our samples represented three stages of the development of bromeliacean carpets in the order Pit $1<$ Pit $2<$ Pit3. In all three cases the cyanobacterial crust was well developed, its thickness increasing in the same order as above (Table 1). Notice that the absence of replication was dictated by the need to avoid destruction of the regeneration niche of the savane roche at the surface of the inselberg. Sampling of plants and animals (invertebrates included) should be minimized, too, in such fragile, surface-restricted,

environments. We sampled the humus profile and the soil for arthropods on 1 and 2 May 2002, during a rainy period. 


\section{Sampling of fauna}

For sampling soil arthropods, a 15-cm diameter and 10-cm deep stainless steel cylinder was forced by hand into the crust, without discarding any debris, until the granite was reached. The whole content of the cylinder was thoroughly excavated with a spoon, then put in a plastic bag before transport to the laboratory (Brunoy, France). The extraction of soil arthropods was done by the dry funnel method (Edwards \& Fletcher, 1971). Animals escaping the desiccating samples were preserved into $95 \%$ ethyl alcohol until we could study them. They were separated into morphospecies, on the basis of characters observable under a dissecting microscope, then classified in broad taxa (Table 1). This allows thorough comparisons between samples and calculation of biodiversity indices, using morphospecies in place of true species as unit taxa, in case species names are unknown (Oliver \& Beattie, 1996).

Densities of animals were used for the calculation of total abundance of arthropods and number of morphospecies per sample. We measured the size of all morphospecies (overall length of the body, appendices excluded) to the nearest 0.04 $\mathrm{mm}$, using a calibrated reticle in the eye piece. For each morphospecies we selected the size of fully developed specimens (adults). This allowed us to calculate the mean potential size of morphospecies in a given sample, by averaging that of all individual taxa.

Sampling of humus profiles 
Three samples (which we denote Pit1, Pit2, and Pit3) were taken in the immediate vicinity of samples for fauna extraction. A block of humus $25 \mathrm{~cm}^{2}$ in area was cut with a sharp knife, with as little disturbance as possible, until the granite was reached $(2,7.5$ and $2 \mathrm{~cm}$ depth, respectively), and the crust surrounding it was gently excavated, preserving the zone where soil animals were to be sampled the day after. The various layers within the blocks were distinguished by eye in the field. Each layer was fixed immediately in $95 \%$ ethanol. The thickness of each layer was measured and annotated according to the nomenclature of Brêthes et al. (1995), which was adapted for biological crusts. The organic horizons were classified into OL (intact crust) and $\mathrm{OH}$ (humified crust), other soil horizons being absent. When several layers were sampled in the same horizon (on the basis of visible differences), sub-samples were numbered successively, for example $\mathrm{OH} 1, \mathrm{OH} 2$ and $\mathrm{OH} 3$. Samples of plants growing nearby $(P$. geyskesii, C. minor, Scleria cyperina Willdenow ex Kunth) were also taken and preserved in ethyl alcohol to allow subsequent identification of plant debris.

In the laboratory, we spread each sub-sample (layer) gently with our fingers in a petri dish, taking care not to break the aggregates; the petri dish was then filled with 95\% ethanol. Plant samples from the site were also placed in alcohol. The soil specimens were examined under a dissecting microscope at $50 \mathrm{X}$ magnification with a cross reticle in the eye piece. A transparent film with a 200-point grid was placed above the preparations. At each grid point, using the reticle as an aid for fixing the position, we identified and counted the material beneath it. The relative volume percentage of a given component was estimated by the ratio of the number of points identified to the total number of points inspected. 
The various kinds of plant debris were identified visually by comparison with reference plant samples. Litter components (leaves, twigs) were classified according to plant species and decomposition stages on the basis of morphological features. Animal faeces were classified according to animal groups when possible, on the basis of previous experience with temperate (Ponge, 1991a, b; Topoliantz et al., 2000) and tropical soils (Topoliantz, 2002). When necessary, the identification of humus components was checked at higher magnification. For that purpose, a small piece of a given humus component was collected with scissors then mounted in a drop of chlorallactophenol for examination in a phase contrast microscope at $400 \mathrm{X}$ magnification.

After quantification of humus components was completed, each petri dish was thoroughly inspected under the dissecting microscope, in order to collect all enchytraeids that were present in the corresponding layer. This allowed us to add these terrestrial annelids to morphospecies extracted as mentioned above, by extrapolating their numbers to the same surface area $\left(1.8 \mathrm{dm}^{2}\right)$. Notice that estimates of enchytraeid densities were not done on the same samples as for arthropods, but on samples taken in the immediate vicinity. Some animals were mounted in chloral-lactophenol for examination of their gut contents by transparency under phase contrast (Ponge, 1991a, b).

\section{Data analysis}

In the absence of replication within each biological crust studied, we did not attempt statistical tests on our faunal data. However, to compare the species richness of our three samples on the same volume basis (thus avoiding artefacts due to variable 
sampling effort), we calculated the theoretical number of morphospecies per $20 \mathrm{~cm}^{3}$ by a jackknife method (Legendre \& Legendre, 1998). For that purpose we divided the total number of arthropods found in a given sample $\left(20 \mathrm{~cm}^{2}\right.$ section, variable depth) by its thickness in $\mathrm{cm}$. This allowed us to estimate the number of arthropods, had our sampling effort been restricted to only one $\mathrm{cm}$ of humus. This estimate was used for a random selection of arthropods within the total population, this sub-sample being used for a new calculation of the number of morphospecies. The same process was replicated ten times, allowing to compute an average value. We found that ten replicates were enough to give a confidence interval (standard error of the mean times Student's $t$ ) of less than $10 \%$ of the mean. This procedure allowed non-biased estimates of biodiversity when comparing samples of varying size (here the volume of soil sampled varied from 0.35 to $\left.0.7 \mathrm{dm}^{3}\right)$.

Percentages of occurrence of humus components in the various layers of the three humus profiles investigated were subjected to correspondence analysis (CA), a multivariate method using the chi-square distance between individuals and between variables in a symmetrical manner (Greenacre, 1984). The different classes of humus components were the active (main) variables, coded by their percentage of occurrence by volume, estimated by the corresponding number of points divided by the total number of points counted. The three plots (Pit1, Pit2, and Pit3) were treated as passive (additional) variables, i.e. they were projected on the factorial axes as if they had been involved in the analysis, without contributing to the factorial axes.

In order to give the same weight to all variables (active and passive) they were transformed to mean 20 and unit variance by 


$$
X=(x-m) / s+20,
$$

where $x$ is the original value, $m$ is the mean of a given variable and $s$ is its standard deviation. The addition to each standardized variable of a constant 20 made all values positive, because correspondence analysis deals only with positive numbers, commonly counts. Following this transformation, factorial coordinates of variables can be interpreted directly in terms of their contribution to the factorial axes. The transformation used here gives to correspondence analysis most properties of the wellknown principal components analysis, while keeping the advantage of the simultaneous projection of variables and samples on the same factorial axes and the robustness due to the principle of distributional equivalence.

\section{Results}

The composition of humus profiles

We identified 71 humus components in the 10 layers we sampled in the three pits (Table 2). They were pooled into 14 gross classes on the basis of affinities in their composition. Notice that these gross classes were not mutually exclusive. For instance, all components comprising pieces of intact cyanobacterial crust were included in the gross class 'intact crust', while some of them were also included in other gross classes (Table 2). This allowed an overview of the vertical distribution of humus components in the three profiles (Figure 2). 
The two thinnest biological crusts, Pit1 and Pit2, corresponding to the smallest bromeliacean carpets, exhibited strong affinities (Figure 2). Both comprised an intact crust overlying a thin layer made of roots of $P$. geyskesii and assemblages of humus (strongly transformed organic matter) and cyanobacteria (visible as intact cell files under the dissecting microscope). No animal biogenic structure was visible, and living cyanobacteria were present over the whole humus profile. Fungi (mycelial wefts) were visible in the top first $\mathrm{cm}$, but disappeared below. Plant litter was almost absent. In these two cases plants (here only P. geyskesii) contributed by their root systems, not by their aboveground parts. No trace of animal activity (faecal deposits) was visible. We observed that the humus material was not firmly aggregated, spilling out easily in the petri dishes even after ethyl alcolhol had precipitated colloids.

In contrast, Pit 3 contained a large volume of enchytraeid faeces, making up to $35 \%$ of the total solid matter (Figure 2). The intact cyanobacterial crust was overlaid by a thin litter, made of flower stems of $P$. geyskesii and leaf fragments of $C$. minor. Below the crust, decayed litter was present, making up to $52 \%$ of the total solid matter, except in the bottom-most $\mathrm{cm}$ where roots dominated the matrix (46\%). The percent in volume of amorphous humus without cyanobacteria increased from the top to the bottom of the humus profile. There was a small amount of mite faeces, mainly in the cyanobacterial crust. Few free cyanobacteria were visible, unlike Pit1 and Pit2. More mineral particles were also present in Pit3 than the two other profiles, and we observed that the humus material was firmly aggregated.

Correspondence analysis, made on all humus components (71), revealed that two major factors influenced the composition of humus layers (Figure 3). Axis 1 (29\% of 
total variance) displayed the vertical distribution of humus components, while axis 2 ( $21 \%$ of total variance) displayed differences between the three crusts. The surface layers (OL horizon) were projected on the positive (right) side of Axis 1, while deeper layers ( $\mathrm{OH}$ horizon) were projected on the negative (left) side of this axis. The distribution of humus layers along axis 1 (Figure 5) showed that more stratification occurred in the composition of the biological crust in Pit3 than in Pit1 and Pit2. Figure 3 (see Table 2 for codes) showed that Pit 3 was characterized by several litter components above the cyanobacterial crust (right side of axis 1), which were replaced by enchytraeid faeces and humified organic matter in the $\mathrm{OH}$ horizon (left side of axis 1). Axis 2 showed that some components were present in Pit1 and Pit2, but not in Pit3. This concerned mainly the composition of the crust, which included mosses, mycelial wefts, humified crust and some particular microbial colonies, which were absent or poorly represented in Pit2.

\section{The soil fauna}

We separated the total arthropod fauna into 54 morphospecies (Table 1). Among arthropods, mites were the most diverse group, amounting half the total number of morphospecies. The group was the most dense per unit surface. Springtails were also dense, although they were much less diverse than the mites. Enchytraeids were present only in Pit3, where they were denser than all other animal groups, amounting 270000 individuals per square metre, more than 3 times the total number of arthropods.

Pit3 was by far the most populated biological crust, both in individuals and in morphospecies (Table 1). We may wonder whether the richness of species observed in 
Pit3 compared with Pit1 and Pit2 was due to sampling effort, the volume of soil extracted being nearly 4 times that of Pit1 or Pit2. In other words, suppose we had taken the same volume of humus, we may wonder whether the number of morphospecies would be the same or not in our three samples. The jackknife procedure showed that, even when reweighted to $1 \mathrm{~cm}$ of humus $\left(177 \mathrm{~cm}^{3}\right)$, the total number of arthropod morphospecies in Pit3 was still more than twice that in Pit1 or Pit2. Thus the increase in species richness we observed in Pit3 was not an artifact caused by our taking a larger volume of humus.

The mean size of arthropod taxa, averaged over all morphospecies present in a sample, was greater in Pit3 than in Pit1 and Pit2 (Table 1). This was due to the presence in Pit3 of bigger mites such as MOR 35' $(1.2 \mathrm{~mm})$ and of macro-arthropod species (arachnids other than mites, millipedes, insect larvae and adults), the size of which often exceeds $1 \mathrm{~mm}$.

Examination of the contents of the enchytraeid guts from Pit2 revealed that these annelid worms ingested a variety of humus components, among which mite faeces, cyanobacteria and fungi were dominant, but a small amount of quartz grains was also observed. The disintegration of mite faeces was evident, suggesting that these animals transformed mite faeces into their own humus (faecal material). Examination of mite faeces within enchytraeid guts revealed a diet only of plant material, with a large amount of dark brownish-red undigested condensed tannins. Humified organic matter (whether included in animal faeces or not) showed, when examined under phase contrast, that bacteria, living and dead, were abundant, and formed the bulk of humus. 


\section{Discussion}

The examination of cyanobacterial crusts under the light microscope revealed profound differences in the composition of humified organic matter depending on whether enchytraeids were present or not. Arthropods, mostly mites, are abundant and diverse in the three profiles, but their faeces do not accumulate, contrary to what has been observed in temperate organic soils (Bal, 1970). In the presence of enchytraeids (in Pit3), most mite faeces are probably ingested by these worms and are transformed into enchytraeid faeces, which accumulate below the cyanobacterial crust. The same substrate succession from mites to enchytraeids has been already observed by Ponge (1991a) in temperate Scots pine litter. Aggregates of humus and living cyanobacteria are common in Pit1 and Pit2, but no mite faeces are recognizable, contrary to expectation, given the high density and diversity of these microarthropods. It seems that mite faeces, which are probably produced in large amount in Pit1 and Pit2, disintegrate rapidly. Part of the resulting colloidal matter is agglomerated by cyanobacteria, forming aggregates of humus and cyanobacteria as observed by Rao \& Burns (1990). In our samples, such aggregates formed a compact horizon, while enchytraeid faeces formed loose assemblages. However, in our alcohol-preserved samples, these aggregates lost particulate matter easily when suspended in alcohol, whereas enchytraeid faeces did not. We suspect that in the presence of intense run-off, crusts without enchytraeids are less stable than those with enchytraeids. Thus, the development of enchytraeid populations creates a structure (Didden, 1990), probably resistant to run-off, allowing crusts to increase in thickness insofar as carbon enters the system via photosynthesis and litter input. The cementation of organic and mineral particles by enchytraeid polysaccharides (mucus) has already been reported (Chan \& Heenan, 1995). 
We observed the establishment by seed of $P$. geyskesii and $C$. minor in the biological crusts upslope of the bromeliacean carpets. The favourable influence of biological crusts on seed capture, germination and establishment of seedlings has been reported (Belnap et al., 2001), and we can readily imagine that the pore network created by enchytraeids (Didden, 1990) can help the development of plant root systems, and can decrease nutrient losses due to run-off (Isichei et al., 1990). The disturbance caused by the burrowing of these animals might also contribute to alleviate competition from already established vegetation. In the same way, the destruction of cyanobacteria in enchytraeid guts can locally decrease their toxicity (Burja et al., 2001), suspected to occur from the census of dominant taxa (Sarthou et al., 1995). Such, still imperfectly known mechanisms could be added to interactions among plants which have been suspected to explain facilitation by early successional plant species on granitic outcrops (Houle \& Phillips, 1989).

We observed fungi and some other microbial colonies in cyanobacterial crusts in the absence of any lichen symbiosis, as did States et al. (2001). We also found that these fungi were preferentially consumed by invertebrates, in particular mites and springtails, although fungal spores and mycelia were much less abundant than cyanobacteria. Thus, fungi could serve as food for microarthropods, although they do not seem to influence the structure of cyanobacterial crusts to a great extent.

The large number of arthropod species in Pit3 was probably mediated by enchytraeid activity, as Loranger et al. (1998) demonstrated to occur with earthworms. In bromeliacean carpets, which are very poor in plant species, the large number of 
invertebrate species we found in associated biological crusts is worth to note, even in the absence of enchytraeid activity. Densities of microarthropods and species richness are similar to values reported by Petersen \& Luxton (1982) for temperate organic soils.

The large arthropod morphospecies in Pit3 can be ascribed to the favourable effect of annelid activity, too. Haarløv (1955) showed that the size of arthropods correlated well with pore and particle size. Also, Loranger et al. (1998) observed that pores and channels created by earthworms favour bigge microarthropods without disfavouring smaller ones, thus increasing biodiversity. Enchytraeids might play the same role as earthworms, by creating space for bigger arthropods in the pore network they create. This, among other processes, might explain why invertebrates of increasing size can be observed in the course of primary successions (Rusek, 1978).

In conclusion, we have identified two distinct steps in the appearance of a pristine soil structure in biological crusts on tropical inselbergs:

(i) a thin crust formed by cyanobacteria, mixed with fungi and other bacterial colonies, that retain humified organic matter loosely attached to cyanobacterial filaments (Pit1 and Pit2)

(ii) a thick crust formed by cyanobacteria and plant litter, covering a structure made of organic enchytraeid faeces, into which plant roots proliferate (Pit3). In that sense, enchytraeids could be considered as ecosystem engineers, as earthworms, termites and ants have been in other kinds of environments.

\section{Acknowledgements}


We thank several state and regional organizations for financial support and commodities, P. Charles-Dominique and his staff at the Nouragues Field Station and P. Chatelet and R. Garrouste for technical help and fruitful discussions.

\section{References}

Bal, L. 1970. Morphological investigation in two moder-humus profiles and the role of the soil fauna in their genesis. Geoderma, 4, 5-36.

Belnap, J. 2001. Factors influencing nitrogen fixation and nitrogen release in biological soil crusts. In: Biological Soil Crusts: Structure, Function, and Management (eds J. Belnap \& O.L. Lange), pp. 241-261. Springer-Verlag, Berlin.

Belnap, J., Prasse, R. \& Harper, K.T. 2001. Influence of biological crusts on soil environments and vascular plants. In: Biological Soil Crusts: Structure, Function, and Management (eds J. Belnap \& O.L. Lange), pp. 281-300. Springer-Verlag, Berlin.

Brêthes, A., Brun, J.J., Jabiol, B., Ponge, J.F. \& Toutain, F. 1995. Classification of forest humus forms: a French proposal. Annales des Sciences Forestières, 52, 535-546.

Burja, A.M., Banaigs, B., Abou-Mansour, E., Burgess, J.G. \& Wright, P.C. 2001. Marine cyanobacteria: a prolific source of natural products. Tetrahedron, 57, 9347-9377. 
Chan, K.Y. \& Heenan, D.P. 1995. Occurrence of enchytraeid worms and some properties of their casts in an Australian soil under cropping. Australian Journal of Soil Research, 33, 651-657.

Didden, W.A.M. 1990. Involvment of Enchytraeidae (Oligochaeta) in soil structure evolution in agricultural fields. Biology and Fertility of Soils, 9, 152-158.

Edwards, C.A. \& Fletcher, K.E. 1971. A comparison of extraction methods for terrestrial arthropods. In: Methods of Study in Quantitative Soil Ecology: Population, Production and Energy Flow (ed. J. Phillipson), pp. 150-185. Blackwell Scientific Publications, Oxford.

Greenacre, M.J. 1984. Theory and Applications of Correspondence Analysis. Academic Press, London.

Grimaldi, M. \& Riéra, B. 2001. Geography and climate. In: Nouragues: Dynamics and Plant-Animal Interactions in a Neotropical Rainforest (eds F. Bongers, P. Charles-Dominique, P.M. Forget \& M. Théry), pp. 9-18. Kluwer Academic Publishers, Dordrecht.

Haarløv, N. 1955. Vertical distribution of mites and Collembola in relation to soil structure. In: Soil Zoology (ed. D.K. McE. Kevan), pp. 167-179. Butterworths Scientific Publications, London. 
Houle, G. \& Phillips, D.L. 1989. Seed availability and biotic interactions in granite outcrop plant communities. Ecology, 70, 1307-1316.

Isichei, A.O., Morton, A.J. \& Ekeleme, F. 1990. Mineral nutrient flow from an inselberg in south-western Nigeria. Journal of Tropical Ecology, 6, 479-492.

Legendre, P. \& Legendre, L. 1998. Numerical Ecology, $2^{\text {nd }}$ English edition. Elsevier, Amsterdam.

Loranger, G., Ponge, J.F., Blanchart, E. \& Lavelle, P. 1998. Impact of earthworms on the diversity of microarthropods in a vertisol (Martinique). Biology and Fertility of Soils, 27, 21-26.

Oliver, I. \& Beattie, A.J. 1996. Designing a cost-effective invertebrate survey: a test of methods for rapid assessment of biodiversity. Ecological Applications, 6, 594607.

Petersen, H. \& Luxton, M. 1982. A comparative analysis of soil fauna populations and their role in decomposition processes. Oikos, 39, 287-388.

Ponge, J.F. 1991a. Succession of fungi and fauna during decomposition of needles in a small area of Scots pine litter. Plant and Soil, 138, 99-113.

Ponge, J.F. 1991b. Food resources and diets of soil animals in a small area of Scots pine litter. Geoderma, 49, 33-62. 
Ponge, J.F., André, J., Zackrisson, O., Bernier, N., Nilsson, M.C. \& Gallet, C. 1998. The forest regeneration puzzle: biological mechanisms in humus layer and forest vegetation dynamics. BioScience, 48, 523-530.

Rao, D.L.N. \& Burns, R.G. 1990. The effect of surface growth of blue-green algae and bryophytes on some microbiological, biochemical, and physical soil properties. Biology and Fertility of Soils, 9, 239-244.

Rusek, J. 1978. Pedozootische Sukzessionen während der Entwicklung von Ökosystemen. Pedobiologia, 18, 426-433.

Sarthou, C. \& Grimaldi, C. 1992. Mécanismes de colonisation par la végétation d'un inselberg granitique en Guyane Française. Revue d'Écologie, La Terre et la Vie, 47, 329-349.

Sarthou, C., Thérézien, Y. \& Couté, A. 1995. Cyanophycées de l'inselberg des Nouragues (Guyane française). Nova Hedwigia, 61, 85-109.

Sarthou, C., Villiers, J.F. \& Ponge, J.F. 2003. Shrub vegetation on tropical inselbergs (French Guiana). Journal of Vegetation Science, 14, 645-652.

States, J.S., Christensen, M. \& Kinter, C.L. 2001. Soil fungi as components of biological soil crusts. In: Biological Soil Crusts: Structure, Function, and 
Management (eds J. Belnap \& O.L. Lange), pp. 155-166. Springer-Verlag, Berlin.

Topoliantz, S. 2002. Réponse Fonctionnelle de la Pédofaune à la Mise en Culture Itinérante et Permanente des Sols du Sud-Ouest de la Guyane Française. Thèse de doctorat, Museum National d'Histoire Naturelle, Paris.

Topoliantz, S., Ponge, J.F. \& Viaux, P. 2000. Earthworm and enchytraeid activity under different arable farming systems, as exemplified by biogenic structures. Plant and Soil, 225, 39-51. 


\section{Figure legends}

Figure 1 A bromeliacean carpet of Pitcairnia geyskesii with its upslope biological crust (Pit2)

Figure 2 The vertical distribution of humus components (pooled in bulk categories, see Table 2) in the three studied profiles. Depth and organic soil horizons in abscissa and percent volume of solid matter in ordinate (scale indicated at the top of the graph)

Figure 3 Correspondence analysis on micromorphological data. Projection of samples and variables in the plane of the first two factorial axes (vertical stratification and differences among profiles, respectively). Top: projection of humus layers (black dots, linked by lines according to vertical succession). Bottom: projection of humus components (meaning of codes in Table 2) and three profiles in the plane of the first two factorial axes. Scale intervals 0.01 . Symbols for humus components and profiles centered on point coordinates 


\begin{tabular}{|c|c|c|c|c|c|}
\hline Morphospecies & Pit1 & Pit2 & Pit3 & size $(\mathrm{mm})$ & \\
\hline MOR 6a & 0 & 1 & 14 & 0.2 & Mites \\
\hline MOR 6b & 0 & 1 & 423 & 0.3 & Mites \\
\hline MOR 6c & 15 & 23 & 34 & 0.4 & Mites \\
\hline MOR 6d & 0 & 0 & 4 & 0.3 & Mites \\
\hline MOR 6d' & 0 & 0 & 2 & 0.3 & Mites \\
\hline MOR 6d" & 0 & 0 & 12 & 0.3 & Mites \\
\hline MOR 6e & 0 & 0 & 127 & 0.4 & Mites \\
\hline MOR $6 f$ & 0 & 0 & 6 & 0.4 & Mites \\
\hline MOR 8 & 0 & 7 & 8 & 0.5 & Mites \\
\hline MOR 9 & 0 & 1 & 62 & 0.8 & Mites \\
\hline MOR 10 & 0 & 8 & 0 & 0.4 & Mites \\
\hline MOR 11a & 0 & 0 & 1 & 0.5 & Mites \\
\hline MOR 11b & 0 & 0 & 1 & 0.5 & Mites \\
\hline MOR 12 & 0 & 3 & 0 & 0.2 & Mites \\
\hline MOR 13a & 35 & 10 & 18 & 0.3 & Mites \\
\hline MOR 13b & 0 & 1 & 0 & 0.5 & Mites \\
\hline MOR 14 & 0 & 1 & 0 & 0.2 & Mites \\
\hline MOR 32 & 45 & 10 & 0 & 0.4 & Mites \\
\hline MOR 33 & 0 & 0 & 85 & 0.7 & Mites \\
\hline MOR 34 & 17 & 0 & 221 & 0.3 & Mites \\
\hline MOR 35 & 0 & 1 & 1 & 0.9 & Mites \\
\hline MOR 35' & 0 & 0 & 5 & 1.2 & Mites \\
\hline MOR 36a & 0 & 0 & 26 & 0.2 & Mites \\
\hline MOR 36b & 46 & 0 & 1 & 0.2 & Mites \\
\hline MOR 37 & 3 & 0 & 8 & 0.2 & Mites \\
\hline MOR 38 & 49 & 0 & 2 & 0.2 & Mites \\
\hline MOR 39 & 0 & 0 & 3 & 0.2 & Mites \\
\hline MOR 24 & 0 & 0 & 2 & 2 & Other arachnids \\
\hline MOR 25 & 0 & 0 & 1 & 0.8 & Millipedes \\
\hline MOR 3a & 53 & 150 & 54 & 0.8 & Springtails \\
\hline MOR 3b & 75 & 33 & 45 & 0.8 & Springtails \\
\hline MOR 4a & 0 & 0 & 4 & 0.4 & Springtails \\
\hline MOR 4b & 0 & 0 & 1 & 0.4 & Springtails \\
\hline MOR 5a & 11 & 0 & 25 & 0.2 & Springtails \\
\hline MOR 5b & 1 & 0 & 1 & 0.3 & Springtails \\
\hline MOR 1 & 1 & 9 & 22 & 2 & Fly larvae \\
\hline MOR 2 & 0 & 5 & 1 & 2.4 & Fly larvae \\
\hline MOR 26 & 0 & 1 & 0 & 1.8 & Fly larvae \\
\hline MOR 40 & 2 & 0 & 0 & 0.4 & Fly larvae \\
\hline MOR 30 & 1 & 0 & 3 & 3.8 & Fly adults \\
\hline MOR 31 & 0 & 1 & 7 & 0.8 & Fly adults \\
\hline MOR 27 & 0 & 0 & 19 & 1.4 & Beetle larvae \\
\hline MOR 28 & 0 & 0 & 3 & 4.8 & Beetle larvae \\
\hline MOR 29 & 0 & 0 & 15 & 1.2 & Beetle larvae \\
\hline MOR 19 & 0 & 0 & 23 & 1.1 & Beetle adults \\
\hline MOR 20 & 1 & 0 & 8 & 2.2 & Beetle adults \\
\hline MOR 21 & 0 & 0 & 1 & 2.1 & Beetle adults \\
\hline MOR 22 & 0 & 0 & 3 & 3 & Beetle adults \\
\hline MOR 15 & 0 & 6 & 41 & 0.4 & Other insect adults \\
\hline MOR 16 & 1 & 0 & 9 & 1 & Other insect adults \\
\hline MOR 17 & 2 & 0 & 13 & 1.3 & Other insect adults \\
\hline MOR 18a & 0 & 0 & 24 & 1 & Other insect adults \\
\hline MOR 18b & 0 & 0 & 1 & 3 & Other insect adults \\
\hline MOR 23 & 3 & 1 & 169 & 0.7 & Other insect adults \\
\hline Thickness & $2 \mathrm{~cm}$ & $3 \mathrm{~cm}$ & $4 \mathrm{~cm}$ & & \\
\hline Total arthropods & 361 & 273 & 1559 & & \\
\hline Total arthropods per $\mathrm{cm}$ & 181 & 91 & 390 & & \\
\hline Number of morphospecies & 18 & 20 & 47 & & \\
\hline Number of morphospecies per & $14.1 \pm 0.4$ & $13.5 \pm 0.5$ & $33.8 \pm 0.7$ & & (mean \pm standard error) \\
\hline Mean size of morphospecies ( $\mathrm{n}$ & 0.86 & 0.74 & 1.00 & & \\
\hline Enchytraeids (estimated) & 0 & 0 & 4916 & 2.2 & \\
\hline
\end{tabular}




\begin{tabular}{|c|c|c|}
\hline Code & Component & Gross category \\
\hline 1 & Flower stem of Pitcairnia geyskesii & Intact litter \\
\hline 2 & Flower stem of Pitcairnia geyskesii covered by cyanobacterial crust & Intact litter + Intact crust \\
\hline 3 & Flower stem of Pitcairnia geyskesii covered by cyanobacterial crust mixed with humified orga & Intact litter + Intact crust + Humus/cyanobactaria aggregates \\
\hline 4 & Flower stem of Pitcairnia geyskesii covered by humified organic matter & Intact litter + Amorphous humus \\
\hline 5 & Flower stem of Pitcairnia geyskesii covered by cyanobacterial filaments & Intact litter + Free cyanobacteria \\
\hline 6 & Flower stem of Pitcairnia geyskesii covered by mite faeces & Intact litter + Mite faeces \\
\hline 7 & Leaf of Clusia minor & Intact litter \\
\hline 8 & Leaf of Clusia minor covered by cyanobacterial crust & Intact litter + Intact crust \\
\hline 9 & Leaf of Clusia minor covered by cyanobacterial crust mixed with humified organic matter & Intact litter + Intact crust + Amorphous humus \\
\hline 10 & Leaf of Clusia minor covered by cyanobacterial crust mixed with animal faeces & Intact litter + Intact crust \\
\hline 11 & Leaf of Clusia minor covered by humified organic matter & Intact litter + Amorphous humus \\
\hline 12 & Leaf of Clusia minor covered by cyanobacterial filaments & Intact litter + Free cyanobacteria \\
\hline 13 & Leaf of Clusia minor covered by orange bacterial colonies & Intact litter + Visible bacterial colonies \\
\hline 14 & Leaf of Clusia minor covered by mite faeces & Intact litter + Mite faeces \\
\hline 15 & Seed pericarp & Miscellaneous \\
\hline 16 & Pollen grain & Miscellaneous \\
\hline 17 & Root & Root \\
\hline 18 & Root covered by enchytraeid faeces & Root + Enchytraeid faeces \\
\hline 19 & Root covered by humified organic matter & Root + Amorphous humus \\
\hline 20 & Root covered by mite faeces & Root + Mite faeces \\
\hline 21 & Decayed plant material & Decayed litter \\
\hline 22 & Decayed plant material covered by mycelial weft & Decayed litter + Fungi \\
\hline 23 & Decayed plant material covered by cyanobacterial filaments & Decayed litter + Free cyanobacteria \\
\hline 24 & Decayed plant material covered by enchytraeid faeces & Decayed litter + Enchytraeid faeces \\
\hline 25 & Decayed plant material covered by humified organic matter & Decayed litter + Amorphous humus \\
\hline 26 & Decayed plant material covered by mite faeces & Decayed litter + Mite faeces \\
\hline 27 & Decayed plant material covered by cyanobacterial crust & Decayed litter + Intact crust \\
\hline 28 & Decayed plant material covered by cyanobacterial crust mixed with enchytraeid faeces & Decayed litter + Intact crust + Enchytraeid faeces \\
\hline 29 & Decayed plant material covered by cyanobacterial crust mixed with humified organic matter & Decayed litter + Intact crust + Amorphous humus \\
\hline 30 & Undetermined translucent plant debris & Decayed litter \\
\hline 31 & Moss & Miscellaneous \\
\hline 32 & Cyanobacterial crust & Intact crust \\
\hline 33 & Humified cyanobacterial crust & Humified crust \\
\hline 34 & Cyanobacterial crust covered by mite faeces & Intact crust + Mite faeces \\
\hline 35 & Cyanobacterial crust covered by orange bacterial colonies & Intact crust + Visible bacterial colonies \\
\hline 36 & Cyanobacterial crust covered by dark green bubble-like cyanobacterial colonies & Intact crust + Free cyanobacteria \\
\hline 37 & Cyanobacterial crust covered by cyanobacterial filaments embedded in a white matrix & Intact crust + Free cyanobacteria + Fungi \\
\hline 38 & Cyanobacterial crust covered by mycelial weft & Intact crust + Fungi \\
\hline 39 & Cyanobacterial crust covered by cyanobacterial filaments embedded in a mycelial weft & Intact crust + Free cyanobacteria \\
\hline 40 & Cyanobacterial crust covered by cyanobacterial filaments & Free cyanobacteria \\
\hline 41 & Undetermined debris covered by cyanobacterial crust & Intact crust \\
\hline 42 & Undetermined debris covered by cyanobacterial crust mixed with humified organic matter & Intact crust + Amorphous humus \\
\hline 43 & Undetermined debris covered by cyanobacterial crust mixed with enchytraeid faeces & Intact crust + Enchytraeid faeces \\
\hline 44 & Isolated cyanobacterial filaments & Free cyanobacteria \\
\hline 45 & Isolated cyanobacterial filaments embedded in enchytraeid faeces & Free cyanobacteria + Enchytraeid faeces \\
\hline 46 & Mycelial weft & Fungi \\
\hline 47 & Arthropod exoskeleton & Miscellaneous \\
\hline 48 & Enchytraeid & Miscellaneous \\
\hline 49 & Enchytraeid faeces & Enchytraeid faeces \\
\hline 50 & Undetermined debris covered by enchytraeid faeces & Enchytraeid faeces \\
\hline 51 & Mite & Miscellaneous \\
\hline 52 & Mite faeces & Mite faeces \\
\hline 53 & Undetermined debris covered by mite faeces & Mite faeces \\
\hline 54 & Humified organic matter & Amorphous humus \\
\hline 55 & Aggregate of humified organic matter & Amorphous humus \\
\hline 56 & Undetermined debris covered by humified organic matter & Amorphous humus \\
\hline 57 & Aggregate of cyanobacteria and humified organic matter & Humus/cyanobacteria aggregates \\
\hline 58 & Undetermined organic aggregate & Amorphous humus \\
\hline 59 & Undetermined organic particle & Amorphous humus \\
\hline 60 & Fine sand particle $(50-200 \mu \mathrm{m})$ & Mineral matter \\
\hline 61 & Coarse sand particle $(200-2000 \mu \mathrm{m})$ & Mineral matter \\
\hline 62 & Coarse sand particle covered by enchytraeid faeces & Mineral matter + Enchytraeid faeces \\
\hline 63 & Coarse sand particle covered by humified organic matter & Mineral matter + Amorphous humus \\
\hline 64 & Coarse sand particle covered by cyanobacterial crust & Mineral matter + Intact crust \\
\hline 65 & Coarse sand particle covered by orange bacterial colonies & Mineral matter + Visible bacterial colonies \\
\hline 66 & Gravel particle (> $2000 \mu \mathrm{m})$ & Mineral matter \\
\hline 67 & Gravel particle covered by enchytraeid faeces & Mineral matter + Enchytraeid faeces \\
\hline 68 & Gravel particle covered by cyanobacterial crust & Mineral matter + Intact crust \\
\hline 69 & Gravel particle covered by humified organic matter & Mineral matter + Amorphous humus \\
\hline 70 & Gravel particle covered by orange bacterial colonies & Mineral matter + Visible bacterial colonies \\
\hline 71 & Gravel particle covered by dark-brown bubble-like bacterial colonies & Mineral matter + Visible bacterial colonies \\
\hline
\end{tabular}




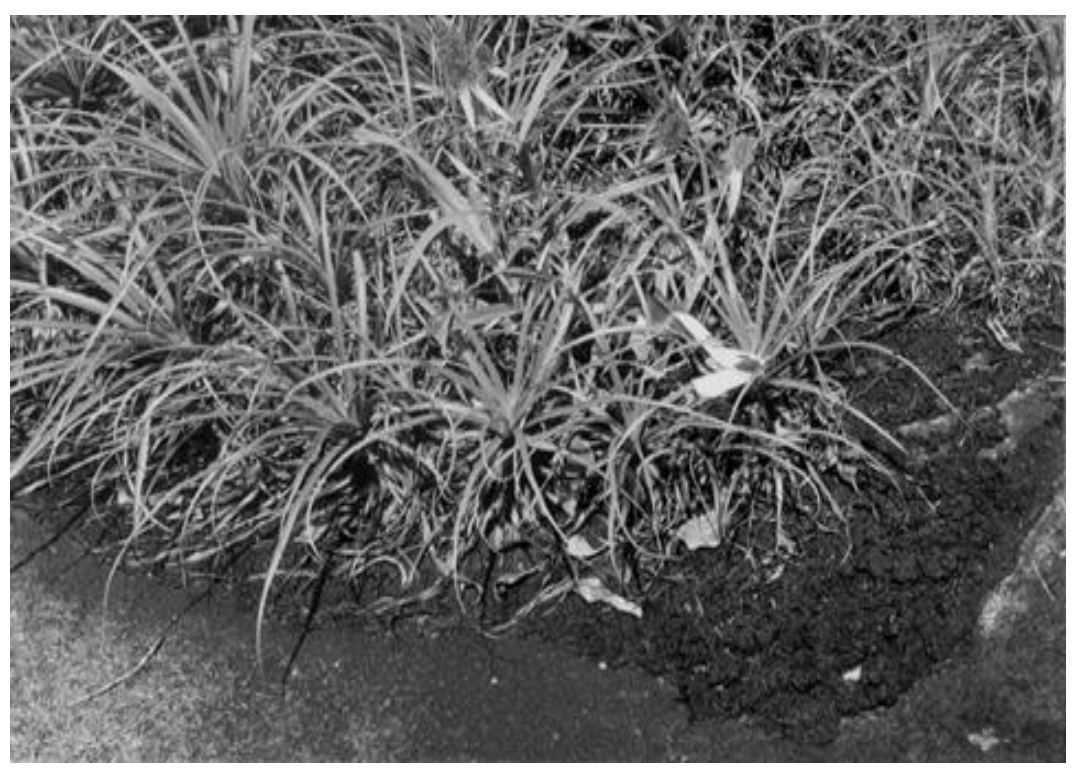

Fig. 1 


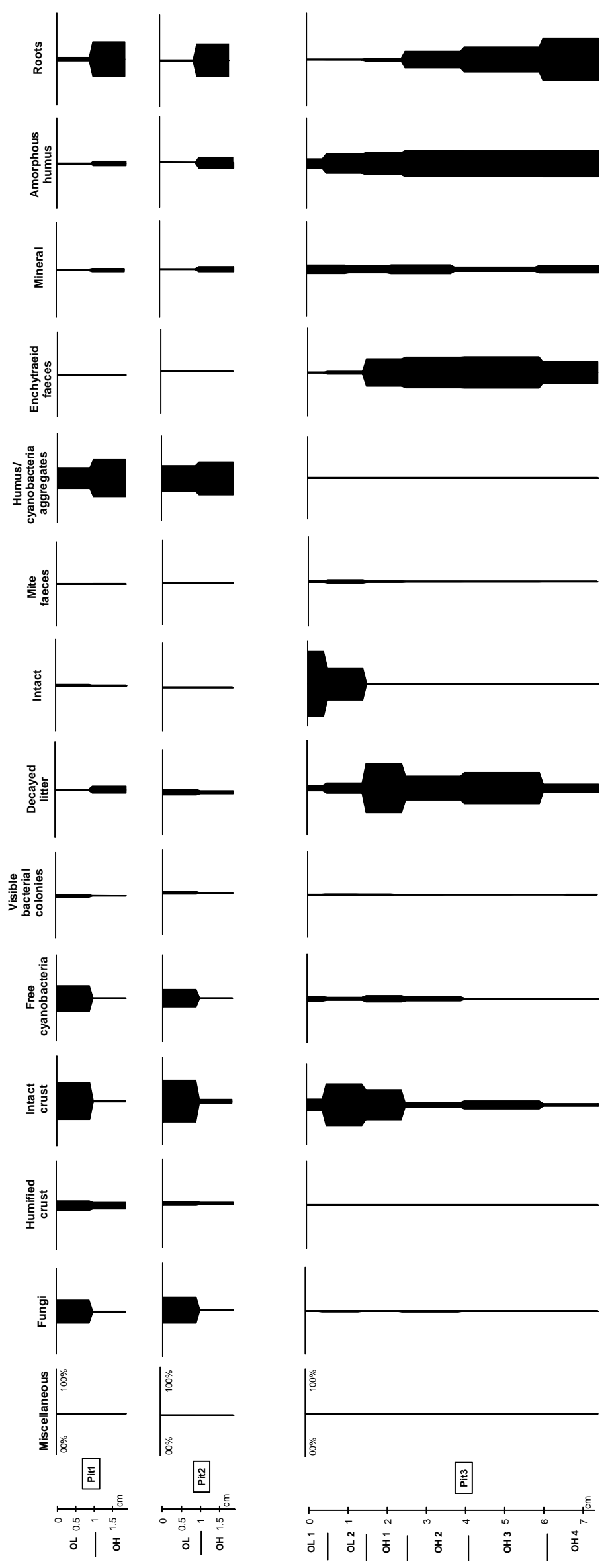

Fig. 2 


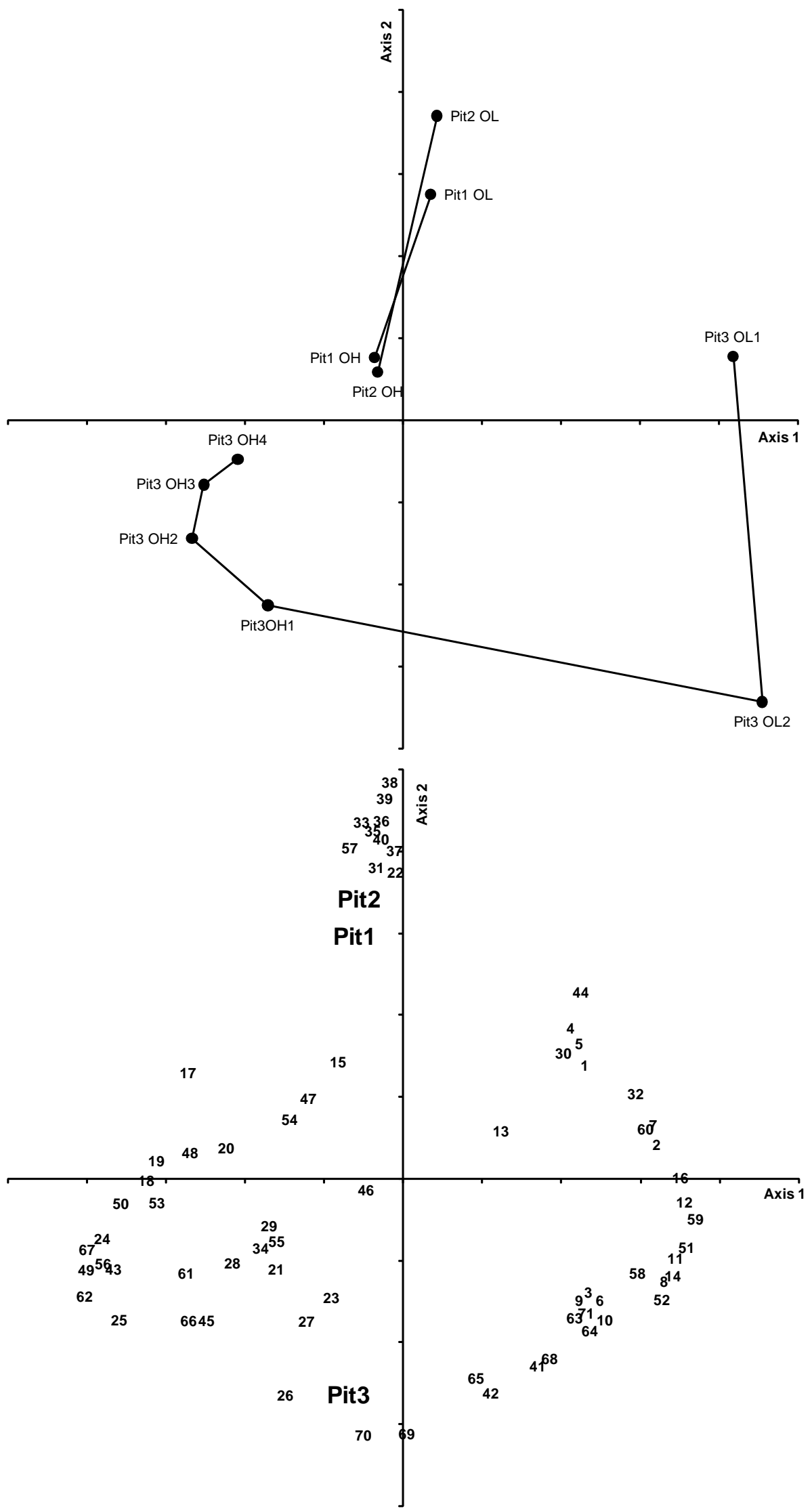

Fig. 3 